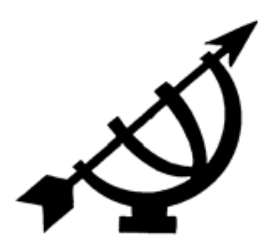

\title{
Menseregte en menswaardigheid
}

\author{
J.D. van der Vyver \\ Departement Internasionale Reg en Menseregte \\ Emory Universiteit \\ ATLANTA \\ Georgia, VSA \\ E-pos: jvyver@law.emory.edu
}

\begin{abstract}
Human rights and human dignity

The concept of human rights includes a variety of entitlements which are commonly subdivided into natural rights of the individual, civil and political rights, economic, social and cultural rights and solidarity rights. It has come to be generally accepted that human rights are based on the principle of human dignity. However, there are instances where human dignity is not recognised as the basic norm of a bill of rights (for example in the USA), and from a Christian perspective human dignity does not represent the core element of being human. Dooyeweerd described the human person as above all being endowed par excellence with religiosity, while Timothy Jackson singled out "sanctity" as the most fundamental basis of human rights protection. This contribution focuses on the need for a Scriptural foundation of human rights.
\end{abstract}

\section{Opsomming}

\section{Menseregte en menswaardigheid}

Menseregte sluit 'n groot verskeidenheid aansprake in wat gangbaar ingedeel word in natuurlike regte van die individu, burgerlike en politieke regte, ekonomiese, sosiale en kulturele regte en solidariteitsregte. Daar word betreklik algemeen aanvaar dat menseregte op die beginsel van menswaardigheid gegrond is. Daar is egter gevalle waar menswaardigheid nie as die basiese norm van 'n menseregtehandves aanvaar word nie (bv in die VSA) en menswaardigheid beeld vanuit 'n Christelike oogpunt ook nie die kernmoment van menswees uit nie. Dooyeweerd beskryf die mens as 'n religieuse wese by uitnemendheid en Timothy Jackson sonder "sanctity" uit as die mees fundamentele grondslag van menseregtebeskerming. 
Hierdie bydrae plaas die behoefte aan 'n Skrifmatige begronding van menseregte in die kollig.

Die beskerming van subjektiewe regte is so oud soos die berge. Maar nie alle regte is "menseregte" binne die betekenis van die leerstuk van menseregte nie. Menseregte sluit slegs daardie subjektiewe regte en vryhede in wat as besonderlik fundamenteel gesien word vir die bestaan van die mens as mens, as burger van die staat, of binne die sosiale strukture van 'n burgerlike samelewing. Die fundamentele aard van menseregte noop die draers van politieke gesag om daardie regte van besondere beskerming te voorsien en om self nie daarop inbreuk te maak nie óf glad en geheel nie, óf slegs nadat aan 'n buitengewone en moeilik haalbare prosedure voldoen is. In sommige gevalle rus daar 'n plig op politieke bewindhebbers om die middele te voorsien wat vir die sinvolle uitoefening van 'n mensereg vereis word. Menseregte is dus beperk tot daardie regte en vryhede wat politieke gesag transendeer en teen, of deur die uitoefening van, regeringsmagte beskerming verg.

Die leerstuk van menseregte vind sy historiese grondslag in die politieke onrus van die sewentiende eeu in Engeland.

\section{Die geslagte van menseregte}

John Locke (1632-1704) het die eerste ontwerp van die leerstuk van menseregte die lig laat sien in Two Treatises of Civil Government (1689), waarin hy die beëindiging van die despotiese bewind van die Engelse koningshuis van Stuart, wat deur die sogenaamde Glorious Revolution (1688) teweeg gebring is, teoreties verantwoord. By hom het dit uitsluitlik gegaan om die natuurlike regte van die individu; daardie regte wat deur Jacques Maritain as "regte van die mens as sodanig" geklassifiseer word en waarby hy die reg op bestaan, op persoonlike vryheid, om die vervolmaking van 'n rasionele en morele lewe na te jaag, en om die ewige lewe te verwerf, insluit (Maritain, 1942:110-113).

Natuurlike regte behels dus daardie regte wat vir die bestaan van die mens as mens onontbeerlik is. Om daardie regte te identifiseer, postuleer Locke die bestaan van die individu in 'n sogenaamde natuurstaat waar almal gelyk is en geen regsvoorskrifte geld of regeerders bestaan nie. Locke postuleer, op grondslag van die gelykheid van alle mense in dié natuurstaat (Locke, 1689:2.2.7), die aanspraak van elke individu op 'n natuurlike reg om beheer oor sy eie lewe uit te oefen. Die mens het ook 'n reg om die voorskrifte van 
sy eie wil na te volg en om aanspraak te maak, as sy eiendom, op alle voorwerpe waarop hy beslag gelê en aan sy eie vormende arbeid onderwerp het - respektiewelik, life, liberty en estate, wat gesamentlik property genoem word. (Locke, 1689:2.9.123; 2.15.173).

Die Suid-Afrikaanse grondwet verleen besondere beskerming aan die natuurlike regte van die individu op gelykheid (Grondwet van die Republiek van Suid Afrika, Wet 108 van 1996, aa 9 en 187), menswaardigheid (a 10) en lewe (a 11).

Jean-Jacques Rousseau (1712-1778) het aan die menseregteidioom 'n heel ander nuanse verleen. Vir hom het dit nie soseer gegaan om die regte wat in 'n natuurstaat aan die individu toekom nie, maar die burgerlike regte wat vir die individu in 'n politieke samelewing van fundamentele belang is. Met die (staatstigtende) sosiale verdrag verloor die mens sy natuurlike individualiteit om deel te word van die politieke gemeenskap - selfs sy individuele wil word opgeneem in die algemene volkswil (la volonté générale) - en hy ruil ook sy natuurlike regte op lewe, vryheid en gelykheid in vir die (andersoortige) burgerlike regte van vryheid, gelykheid, lewe en eiendom. Rousseau herlei aldus die terme van die sosiale verdrag tot 'n enkele mandaat: l'alienation totale de chaque associé avec tous ses droits à toute la communauté (Rousseau, 1762:1.6).

Met die opkoms van die positivisme teen die middel van die negentiende eeu, het die idee van natuurreg en natuurlike regte in die wysgerige hoofstroming 'n slegte naam gekry, en dit het daarom betreklik gangbaar geword om menseregte tot burgerlike en politieke regte te beperk. Daardie kategorie menseregte het sekere algemene kenmerke in gemeen:

- die klem val op aansprake van die individuele mens;

- daardie aansprake word teen hulle inkorting deur politieke bewindhebbers beskerm; en

- van die politieke bewindhebbers word weinig meer vereis as om die uitoefening van die tersaaklik dienende regte te veroorloof.

Daar word soms gesê dat sosiale en politieke regte eerder met "freedom from" as met "rights to" vereenselwig moet word (Marks, 1981:438). Die Duitsers praat in dieselfde trant van Abwehrrechte (Venter, 1986:105).

Burgerlike en politieke regte wat deur die Suid-Afrikaanse grondwet beskerm word, sluit in die reg op persoonlike vryheid en sekuriteit 
(a 12), die reg op privaatheid (a 14), vryheid van godsdiens, geloof en opinie (a 15), vryheid van meningsuiting (a 16), vryheid om vreedsaam te vergader (a 17), vryheid van assosiasie (a 18), politieke regte (a 19), die reg op burgerskap (a 20), vryheid van beweging en verblyf (a 21), die reg op inligting (a 32), die reg op regverdige administratiewe praktyke (a 33) en 'n groot verskeidenheid prosessuele regte (aa 34 en 35 ).

In die vroeë dekades van die twintigste eeu het 'n nuwe kategorie menseregte op die toneel verskyn, naamlik ekonomiese en sosiale regte. Hierdie regte sentreer om regte van die werker, soos die reg op werksgeleenthede, op 'n veilige en gesonde werksomgewing, op redelike vergoeding en gelyke lone vir dieselfde werk, op sosiale versekering, op kollektiewe bedinging en so meer.

Daar was reeds in die Omsendskrywe van Pous Leo XIII, genaamd Rerum Novarum (1891), 'n aansienlike lys van die regte van werkers opgeteken (Van der Vyver, 2005b:hfst. 4), maar daardie regte het eers in die Mexikaanse grondwet van 1917 daadwerklike beslag gekry. Die algemene kenmerke van hierdie groep regte sluit die volgende in:

- ekonomiese en sosiale regte behels in seker die meeste gevalle 'n positiewe plig van die regering om die dienste, fasiliteite en onderskraging te voorsien wat vir die sinvolle genieting van daardie regte onontbeerlik is;

- die klem val hier nie soseer op aansprake van die enkele persoon nie, maar op dié van die individu in 'n bepaalde sosiale konteks, byvoorbeeld as werker, as skoolgaande kind, of as lid van 'n etniese gemeenskap; en

- voorsiening in die behoeftes vir die sinvolle genieting van ekonomiese en sosiale regte is in baie gevalle nie onmiddellik haalbaar nie en daar moet dus voorsiening gemaak word, as 'n dringende faset van regeringsbeleid, vir die progressiewe implementering van die dienste, fasiliteite en onderskraging wat verwerkliking van hierdie regte moontlik sal maak.

In die Suid-Afrikaanse grondwet tref 'n mens die volgende aan: vrywaring teen slawerny en gedwonge arbeid (a 13), vryheid om jou werk, beroep of professie te kies (a 22), arbeidsregte (a 23), beskerming van eiendom teen arbitrêre onteiening (a 25), die reg op behuising (a 26), die reg op gesondheidsdienste, voeding, water en sosiale sekuritiet (a 27), die reg op onderwys (28), en 'n verskeidenheid taal- en kulturele regte (a 30 ). 
Gedurende die vroeë sewentigerjare van die vorige eeu het Karel Vasak, destyds Direkteur van die Internasionale Instituut van Menseregte in Strasbourg, Frankryk, van 'n nuwe geslag menseregte gewag gemaak, wat hy solidariteitsregte genoem het (Vasak, 1974:344-345; Vasak, 1975:2; Vasak, 1977; en vgl ook Marks, 1981:441; Sohn, 1982-1983:61; Alston, 1982:310-311; Donnelly, 1985:491-492). Dit gaan hier om die reg op vrede, die reg op ontwikkeling van agtergeblewe bevolkingsgroepe, of op die internasionale akker van ontwikkelende lande, die reg op natuurbewaring en op 'n gesonde en skoon omgewing, die reg om deel te hê aan daardie dele van die heelal wat deur die volkereg as die gemeenskaplike erfenis van die mensdom uitgesonder word, en dies meer (Sohn, 1982-83:48-62; Shestack, 1984:99-101; Lillich, 1991:179-185).

Vasak staan vir die idee van geslagte van menseregte vader. Vasak beklemtoon dat die geslagtekonsep nie 'n hiërargie van menseregte impliseer nie, maar bloot die historiese volgorde aandui waarin die verskillende soorte menseregte teoreties onderskei is.

Solidariteitsregte openbaar die volgende algemene kenmerke:

- die klem val hier nie meer op aansprake van die individu nie, maar op bevoordeeldes wat kollektief aangedui word, in die sin van byvoorbeeld die mensheid as geheel, 'n bepaalde politieke gemeenskap, of 'n besondere deel van die bevolking;

- die bevoordeeldes van solidariteitsregte is nie beperk tot personae in esse nie, maar sluit ook toekomstige geslagte in; en

- solidariteitsregte kan in die meeste gevalle nie voldoende deur munisipale menseregte-aktes beskerm word nie, maar vereis internasionale samewerking op wêreldwye skaal of binne 'n bepaalde streek (besoedeling kan byvoorbeeld nie voldoende binne landsgrense bekamp word nie).

In die Suid-Afrikaanse grondwet word beskerming beloof vir sodanige regte in die geval van omgewingsregte (a 24), die reg op ontwikkeling wat deur herstellende aksie bevorder word as aanhangsel tot die reg op gelykheid (a 9(2)), eiendomsregte (a 25(6)-(9)), die reg op onderwys (a 29(2)(c)), en die reg op selfbeskikking van kulturele, godsdienstige en taalgemeenskappe (aa 31, 185-186 en 235).

Die klassifikasie van menseregte wat dusver aan die orde gekom het, is nie absoluut nie. Die reg op godsdiensvryheid is byvoorbeeld 
'n natuurlike reg van die individu, maar die manifestasie van daardie reg geskied binne die sosiale verband van geloofsgemeenskappe en geld as sodanig ook as 'n burgerlike reg binne die staatsverband. Die reg om jou kulturele belange te bevorder, hoort na sy inhoud tot die sosiale regte van kultuurgenote, maar vereis nie die voorsiening van dienste, fasiliteite of onderskraging deur die staatsowerheid nie. Verwerkliking van gelyke geleenthede op die gebied van ekonomiese en sosiale regte kan onmiddellik verwerklik word en hoef daarom nie aan progressiewe implementering onderworpe gestel te word nie.

\section{Menswaardigheid}

Menseregte, verklaar Bas de Gaay-Fortman (van die Vrije Universiteit) in sy intreerede as professor in Politieke Ekonomie en Menseregte aan die Universiteit van Utrecht, verteenwoordig 'n poging om menswaardigheid te beskerm (De Gaay-Fortman, 2001).

Sedert die Pouslike Omsendskrywe Pacem in Terris (1961) vorm menswaardigheid ook die grondslag van die Rooms Katolieke sosiale teorie. Veral in die Verklaring van Godsdiensvryheid (Dignitatis Humanae Personae) beklemtoon die Tweede Vatikaanse Beraad (1962-1965) "the very dignity of the human person", wat luidens dié Deklarasie deur die Woord van God en die rede self geopenbaar word. Selfs lank tevore het Pous Leo XIII in Rerum Novarum (1891) van die standpunt uitgegaan dat menswaardigheid die standaard is van alle reg. "Godsdiens leer die ryk mense," verklaar Leo XIII, "dat hulle werksmense nie slawe is nie; dat hulle in elke persoon sy waardigheid as mens en as Christen moet respekteer" (Leo XIII, 1891:par. 21); en nogmaals: "Geen mens mag met onvatbaarheid daardie menswaardigheid verkrag wat deur God self met hoogagting aangesien word nie" (Leo XIII, 1891:par. 43). Michael Perry, 'n kontemporêre eksponent van die menseregte ideologie vanuit 'n Rooms Katolieke agtergrond, verklaar: "The morality of human rights holds that every human being has inherent dignity and is therefore 'inviolable': not to be violated" (Perry, 2005:103). 'n Persoon word volgens Perry ge-violate (onteer) deur 'n (positiewe of negatiewe) handeling of beleid indien die logiese grond vir daardie handeling of beleid ontken dat die betrokke persoon waardigheid het, of daardie persoon behandel asof hy/sy nie inherente waardigheid besit nie (Perry, 2005:102-103).

Perry se veronderstelling dat die mens as die draer van waardigheid onskendbaar of onaantasbaar is, is besonderlik aanvegbaar (vgl. Van der Vyver, 2005a:198). Onaantasbaarheid word wel in mense- 
regtetaal gebruik om daardie regte en vryhede aan te dui wat nie in 'n noodtoestand aan enige beperkings onderworpe gestel mag word nie (vgl in die Suid-Afrikaanse Grondwet, a 37(5)). Dit geld ingevolge die Internasionale Verdrag van Burgerlike en Politieke Regte (1966) vir die reg op lewe, vrywaring teen marteling, die verbod op slawerny en gedwonge arbeid, die verbod op siviele gyseling, die reël wat die terugwerkende instelling van misdade verbied en die reg op regsubjektiwiteit (a 4(2) van die Verdrag). Dit is dus bepaalde regte en vryhede wat onaantasbaar is en nie die mens as draer van daardie regte en vryhede nie. Regte en vryhede wat wel tydens 'n nasionale noodtoestand ingekort kan word (Verdrag, a 4(1)), is wél aantasbaar.

Sekere menseregte impliseer wel onskendbaarheid van die persoon - nie alle menseregte nie, maar slegs dié wat toegespits is op die beskerming van lyf en lewe. Die toepaslike lys van regte en vryhede wat in die Internasionale Verdrag van Burgerlike en Politieke Regte vermeld word, is beperk tot die reg op lewe en vrywaring teen marteling.

Menswaardigheid word ook in volkeregtelike konvensies tot die kern van menseregtebeskerming geproklameer. Die Universele Deklarasie van Menseregte (1948) en die Internasionale Verdrag van Burgerlike en Politieke Regte (1966) verklaar albei in hulle onderskeie voorredes dat "recognition of the inherent dignity and of the equal and inalienable rights of all members of the human family is the foundation of freedom, justice and peace in the world" (beklemtoning bygevoeg - JDvdV). Volgens die voorrede van die Deklarasie vir die Eliminering van Alle Vorme van Onverdraagsaamheid en Diskriminasie gegrond op Godsdiens of Geloof (1981) is die Deklarasie gebaseer op die basiese beginsels van die Oktrooi van die Verenigde Nasies wat "the dignity and equality inherent in all human beings" voorop stel.

Maar is menswaardigheid noodwendig 'n gewenste vertrekpunt vir die bevordering en beskerming van menseregte?

\subsection{Menseregtebeskerming sonder menswaardigheids- beskerming}

Daar word dikwels gesê dat die regte en vryhede wat in 'n grondwetlike menseregtehandves beskerm word, gelyke aansien geniet en dat daar nie 'n rangorde van menseregte bestaan nie (Gardiner v Whitaker, 1994 (5) BCLR 10 (EC) par. 36A, 36 E-F; Van Zyl v Jonathan Ball Publishers (Pty) Ltd, 1999 (4) SA 571591 (W); 
Laerskool Middelburg v Departementshoof, Mpumalanga, 2003 (4) SA $160178(T)$ ). Regter Yacoob verklaar dus in die bekende Grootboom-saak dat die grondwetlik beskermde regte onderling verwant is en mekaar aanvul (Government of the RSA \& others $v$ Grootboom \& others, 2001 (1) SA 46 (CC); 2000 (11) BCLR 1168 (CC) par. 23; en vgl ook Khosa \& others $v$ Minister of Social Development \& others; Mahlaule \& others $v$ Minister of Social Development \& others, 2004 (6) SA 505 (CC) par. 40). Vir sover hiermee te kenne gegee wil wees dat burgerlike en politieke regte aan die een kant en ekonomiese en sosiale regte aan die ander kant nie op 'n hiërargiese skaal teen mekaar afgespeel moet word nie, kan met die stelling saamgestem word. Indien die een grondwetlike reg of vryheid egter met ' $n$ ander een in onversoenbare botsing kom, moet voorrang gegee word aan dié een wat ten nouste met die mees fundamentele reg of vryheid verband hou.

Dit is waarskynlik dat elke grondwet met ' $n$ menseregtehandves voorrang verleen aan 'n bepaalde reg of kategorie regte. Daardie voorkeur berus op die basiese norm, die Grundnorm, van die hele grondwetlike stelsel, wat op sy beurt nóú verbonde is aan die historiese omstandighede wat aanleiding gegee het tot, of wat gegeld het tydens, die oorspronklike ontwerp van die grondwet. Die basiese norm druk sy stempel af op die hele grondwetlike bedeling.

Baie grondwetlike stelsels baseer inderdaad die struktuur van menseregte op die kernbeginsel van menswaardigheid. Die SuidAfrikaanse grondwet, byvoorbeeld, proklameer 'n hiërargie van grondwetlike waardes, wat bestaan uit waardigheid, gelykheid en vryheid (in daardie rangorde) (arts. 1(a), 7(1), 36(1)). In een van sy vroegste uitsprake het die Grondwetlike Hof verklaar dat hy 'n hoë premie op menswaardigheid plaas (S v Williams, 1995 (2) SA 632 (CC), 1995 (7) BCLR 861 (CC) par. 76). In die Hof se heel eerste uitspraak verklaar Chaskalson, P. ( $v$ Makwanyane \& another, 1995 (3) SA 391 (CC) par. 144):

The right to life and dignity are the most important of all human rights, and the source of all other personal rights in chap 3. By committing ourselves to a society founded on the recognition of human rights we are required to value these two rights above all others.

Regter O'Regan beklemtoon menswaardigheid in dieselfde saak as "a founding value of the new Constitution" ( $S$ v Makwanyane \& another, 1995 (3) SA 391 (CC), par. 328). Regter O'Regan het by een geleentheid die historiese basis van hierdie toedrag van sake 
soos volg verduidelik (Dawood, Shalabi \& Thomas $v$ Minister of Home Affairs, 2000 (3) SA 936, 2000 (8) BCLR 837 (CC) par. 35):

The value of dignity in our Constitutional framework cannot ... be doubted. The Constitution asserts dignity to contradict the past in which human dignity for black South Africans was routinely and cruelly denied. It asserts it too to affirm the future, to invest in our democracy respect for the intrinsic worth of all human beings. Human dignity therefore informs constitutional adjudication and interpretation at a range of levels. It is a value that informs the interpretation of many, possibly all, other rights.

Die Amerikaanse grondwetlike bedeling, aan die ander kant, is in wese 'n libertêre stelsel. Daar geniet menswaardigheid geen prioriteit, en selfs geen grondwetlike beskerming nie. Die Amerikaanse menseregtehandves beperk sy beskerming uitsluitlik tot burgerlike en politieke regte, sonder om enige natuurlike regte (bv. die reg op lewe en op menswaardigheid) daarby in te sluit. Binne die kader van burgerlike en politieke regte geniet die Eerste Amendament vryhede (godsdiensvryheid, vryheid van spraak, persvryheid en die reg om die regering te petisioneer vir die bylegging van griewe) besondere voorkeur. Regter Powell het in een van sy (minderheids-) uitsprake verklaar die Eerste Amendament "embodies out Nation's commitment to popular self-determination and our abiding faith that the surest course for developing sound national policy lies in a free exchange of views on public issues" (Saxbe v Washington Post Co., 417 US 843 (1974) 862-863). Enige beperking van vryheid van spraak, vir welke rede ook al, sal ongrondwetlik verklaar word, behalwe in hoogs uitsonderlike gevalle. Aangesien menswaardigheid ondergeskik is aan vryheid van spraak, is die lasterreg in die VSA afgeskaal tot 'n nommer op 'n kontrak. Pogings van State (provinsiale wetgewers) om aangeleenthede soos kinderpornografie en haatspraak aan bande te lê, word keer op keer in die belang van vryheid van spraak ongrondwetlik bevind. (Vgl. wat kinderpornografie betref: Reno $v$ American Civil Liberties Union, 521 US 844 (1997); American Civil Liberties Union v Reno, 217 F 3d 162 (3rd Cir, 2000); United States v Playboy Entertainment Group Inc., 529 US 803 (2000); Aschcroft v Free Speech Coalition, 535 US 234 (2002); en wat haatspraak betref: RAV v City of St Paul, 505 US 377 (1992).) In sekere gevalle is wetgewing wat voorsiening maak vir swaarder strawwe in gevalle waar 'n geweldmisdaad deur haat vir 'n bepaalde groep gemotiveer is, wel grondwetlik bevind omdat dit sogenaamd ' $n$ handeling is wat die swaarder strawwe regverdig en nie spraak nie (State $v$ Mitchell, 508 US 476 (1993); vgl. ook Virginia v Black, 538 US 343 (2003)). 
Dit spreek vanself dat in regstelsels waar menswaardigheid voorop gestel word en voorrang geniet bo vryheid van spraak, die bekamping van kinderpornografie en haatspraak geen grondwetlike struikelblokke sal ervaar nie.

Daar skuil 'n klaarblyklike anomalie in die voorveronderstelling dat menseregte op die beskerming van menswaardigheid gebaseer is, terwyl daar regstelsels is, soos dié een van die VSA, waar menswaardigheid nie die primêre waarde is waarom dit gaan nie.

\subsection{Historiese stigma wat aan menswaardigheid kleef}

Die begrip dignitas dra 'n wavrag historiese bagasie met hom saam. Dit het heelwat Christelike denkers na 'n ander woord laat soek om die diepste, mees fundamentele attribuut van mens-wees saam te vat.

In die Romeinse tyd het dignitas 'n sekere hoogwaardigheid aangedui; 'n teken van gesag wat aan persone verbind is wat politieke mag oor andere uitgeoefen het. Die Romeinse actio iniuriarum, wat privaatregtelike beskerming verleen het aan die sogenaamde persoonlikheidsregte (die reg op corpus - liggaamlike integriteit), dignitas (waardigheid) en fama (aansien in die gemeenskap), het waarskynlik dignitas as 'n generiese begrip bedoel en nie soseer as 'n persoonlike elitistiese modaliteit van 'n bevoorregte klas nie. Sommige mense, soos slawe en ongeëmansipeerde persone, is nietemin van die beskerming wat daardie aksie gebied het, uitgesluit.

Timothy Jackson, mede-professor in Christelike etiek aan die Candler Skool vir Teologie van Emory Universiteit, beskou waardigheid daarom as 'n term wat ten minste 'n outonome en rasionele subjek veronderstel - iemand met "a robust sense of self", wat derhalwe kinders, geestesongestelde persone en die ongeborene uitsluit (vgl. veral Jackson, 2003a: hfst. 5; Jackson, 2003b: hfst. 5). Soos wat die term deur Anglo-Amerikaanse filosowe gebruik word, verwys "dignity" terug na sy Latynse oorsprong (dignitas); dus as 'n term wat prestasie, persoonlike mag of 'n gesagsposisie aandui. In teenstelling met fama, dui dignitas op die self-beeld van die reghebbende en kan genoegdoening derhalwe nie met die actio iniuriarum geëis word indien die slagoffer van 'n waardigheidskendende handeling onbewus is van daardie handeling nie. 


\section{Die alternatief}

Die probleem waarmee menseregte eksponente opgeskeep sit, is om 'n gepaste woord te vind wat die kernmoment, die mees fundamentele attribuut, van mens-wees raakvat. Herman Dooyeweerd (1894-1977) gee 'n antwoord op dié vraag deur die mens as 'n religieuse wese by uitnemendheid te verbesonder. Daarby is die idee inbegryp dat die mens in 'n direkte verhouding tot God staan en in al sy doen en late óf tot eer van God, óf tot sy oneer handel. Religie in dié sin word van godsdiens (die direkte diens van God deur belydenis, aanbidding, kerkbesoek en so meer) onderskei.

Hiermee loop 'n mens in die Anglo-Amerikaanse wêreld 'n probleem op die lyf, want religie en godsdiens kan in Engels slegs met dieselfde woord (religion) weergegee word. Om religion in die Dooyeweerdse sin van religie tuis te bring, vereis ellelange omskrywings en verduidelikings, wat dikwels vir die oningewyde Engelse luisteraar net meer verwarrend is. Religie kan miskien ten beste in Engels as 'n gegewe religiosity beskryf word.

Professor Jackson, na wie se kommer oor die gebruik van dignitas om die essensie van mens-wees aan te dui, hierbo verwys is, verkies die term sanctity, wat weer in Afrikaans nie aan heiligheid gelykgestel moet word nie. Sanctity dui op 'n gegewe basis vir menslike behoeftes, vermoëns en potensies - en mees sentraal, die behoefte of die vermoë om liefde te betoon en te ontvang (agape). Anders as waardigheid in die tegniese sin, besit alle menslike persone hierdie basis van sanctity en dit moet eerbiedig word vóór, en onafhanklik van, enige bykomstige verdienste of onverdienstelikheid.

Professor H.G. Stoker (1899-1993) het gedurende sy later jare met dieselfde probleem binne die konteks van menseregte geworstel (Stoker, 1970; en vgl. ook Van der Vyver, 1974). Stoker het soos die natuurregsfilosowe van ouds, die basiese regte van die mens probeer ontbloot met 'n bepaalde situasie-gebonde voorveronderstelling voor oë. Maar terwyl Locke en sy tydgenote die natuurlike regte van die mens probeer ontrafel het deur die bestaan van die individu in 'n sogenaamde natuurstaat te (re-)konstrueer, gaan dit vir Stoker as eksponent van 'n Skrifmatige wysbegeerte, om die mens as skepsel van God. Stel jouself die mens voor op die veronderstelling dat daar geen sonde en sondeval was nie. Stoker aanvaar naamlik as 'n geloofswaarheid dat die mens deur die sonde wel bedorwe geraak het, maar dat die kern van sy/haar mens-wees nie deur die sondeval ongedaan gemaak is nie. Die diepste sin van 
mens-wees kan daarom, volgens Stoker, vasgestel word deur die invloed van sonde op die eksistensiële mens kenteoreties weg te dink.

Langs hierdie weg besluit Stoker dat elke mens 'n ontiese reg (in die enkelvoud) het om sy spesiale en persoonlike godgegewe roeping in die lewe te vervul. Ontiese reg is die term wat hy verkies vir die mees fundamentele reg van die mens as mens. Op sterkte van die ontiese reg om jou godgegewe roeping te vervul, het Stoker alle wette en sosiale instellings veroordeel wat die verwerkliking van hierdie basiese reg in die wiele mag ry.

\section{Slotwoord}

In die vroeë sewentigerjare van die vorige eeu het die $\mathrm{PU}$ vir $\mathrm{CHO}$ die eerste Suid-Afrikaanse universiteit geword wat 'n kursus in menseregte by sy leerplan vir regstudente ingesluit het - en nogal as 'n verpligte vak. Wits het min of meer dieselfde tyd ook 'n kursus met 'n menseregte-inhoud begin aanbied, maar die vak is aldaar Aspects of Public Law genoem. Professor John Dugard het verduidelik dat die vrese by Wits bestaan het, dat as hulle die kursus Human Rights sou noem, die owerhede dit nie sou goedkeur nie. Toe hierdie skrywer in 1979 by die regsfakulteit van Wits aangesluit het, het Aspects of Public Law binne sy doseeropdrag tereg gekom, en is die naam, met algemene instemming, na Human Rights verander.

Die kursus in menseregte het ruimte gebied vir heelwat kritiese insette wat landsbeleid, grondwetlike praktyke en 'n aardige klompie algemene regsvoorskrifte van destyds in die gedrang gebring het. Die studente het na die beste van my wete groot waardering gehad vir beginsel-gegronde oordele wat die juridiese onderskraging van 'n leefwyse bevraagteken het, wat gangbaar met ons nasionale en etniese identiteit - en selfs ons godsdienstige oortuigings vereenselwig is.

Maar dit het ook spannings teweeg gebring. Potchefstroom het destyds bankvas agter die destydse regering gestaan. Apartheid is vanuit 'n gewaande Skrifmatige benadering geregverdig: God het almal na sy aard geskape; rasseskeiding is vir die behoud van onder meer ons Afrikaner identiteit onontbeerlik; apartheid is nie op rasseonderskeidings gebaseer nie, dis 'n kwessie van beskawingsontwikkeling (met 'n beroep op 'n passasie uit die werke van Herman Dooyeweerd); afsonderlike ontwikkeling doen soewereiniteit in eie kring gestant (met 'n beroep op Abraham Kuyper) en klop met 
die volkeregtelike reg op selfbeskikking van nasionale of etniese, godsdienstige en taalgroepe.

Dié Universiteit het soms ook gerieflikheidshalwe anderpad gekyk. Ek herinner my die geval toe die Instituut vir die Bevordering van Calvinisme (soos dit destyds genoem is) op voorstel van prof. Theo van der Merwe besluit het om 'n ondersoek in te stel - vanuit 'n Calvinistiese gesigspunt - na die Suid-Afrikaanse veiligheidswetgewing. Die Raad van die $\mathrm{PU}$ vir $\mathrm{CHO}$ het die ondersoek verbied weens die sensitiewe aard van die onderwerp.

Boonop is die leerstuk van mensregte oor die algemeen met 'n beroep op die Calvinisme verwerp. Die leerstuk stam uit die humanisme en kom op mensverering neer, is gesê. Dooyeweerd self het nie veel ooghare vir die idee van menseregte gehad nie.

Dit het die Potchefstroomse kursus voor groot uitdagings gestel. Die dosente was geroepe om aan die begronding en legitimering van menseregte 'n Skrifmatige inhoud te gee. Daardie roeping bly 'n mens nou nog by en word in hierdie bydrae behandel.

Sedert die vroegste tye het die staats- en politieke wetenskappe formules bedink wat die misbruik van owerheidsgesag aan bande kon lê. Deur die jare is daar lofwaardige meganismes ontdek en in die praktyk gestel om dié doel te dien:

- Die beginsel van demokrasie, wat aan die onderdane van staatsgesag volmag verleen om periodiek diegene aan te wys wat met politieke mag beklee moet word.

- Die skeiding van staatsmagte, wat poog om die konsentrasie van die wetgewende, uitvoerende en regsprekende gesag in die hande van dieselfde persone te vermy.

- Die verdeling van staasgesag tussen 'n sentrale regering en streeks- en plaaslike owerhede in 'n federale bestel.

- Transparante administrasie en verantwoordelike regering, wat ten dele deur 'n vrye en onafhanklike pers gewaarborg moet word.

- Die instelling van 'n ombudsman met bevoegdhede om uitvoerende handelinge van die landsadministrasie te fynkam, ten einde te verseker dat die belange van die onderdane voldoende in berekening gebring word. 
- Die beginsel van soewereiniteit in eie kring, wat 'n private sfeer van individuele vryhede, en die interne aangeleenthede van niestaatlike sosiale instellings, teen inmenging van die regering verskans.

- Die beskerming, in 'n menseregtehandves, van basiese regte en fundamentele vryhede van die onderdane van staatsgesag teen wetgewende inperkings en administratiewe optrede, en die onderwerping van die draers van owerheidsgesag aan 'n verpligting om die dienste, fasiliteite en onderskraging te voorsien wat vir 'n genoeglike, veilige en gesonde bestaan van mense binne staatsverband bevorderlik is.

Daar bestaan vandag dus 'n steeds groeiende volkeregtelike etos vir goeie landsbestuur, wat geskoei is op die breë beginsels van transnasionale welwillendheid, demokrasie en menseregte. Die besondere fasette van hierdie globale moraliteit het vir die grootste deel uit sekulêre denke ontstaan gedurende 'n tyd toe die hoof godsdienstige strominge vernuwings teengestaan het, tot op 'n punt van stagnante konserwatisme of konserwatiewe stagnasie. Die globale moraliteit het daarom nie altyd as gevolg van die heersende godsdienstige leerstellings ontwikkel nie, maar in vele opsigte ten spyte daarvan. By nabaat, na gelang geloofsgerigte instellings die inherente waarde besef het van die nuwe denkbeelde, het hulle onderling begin wedywer om aan te toon dat hulle, elkeen vir homself, eintlik vir daardie denkbeelde verantwoordelik was.

Die Rooms Katolisisme het op dié manier eers met die Tweede Vatikaanse Beraad met die menseregte ideologie vrede gevind. Miskien het die Calvinisme nog nie heeltemal daarby uitgekom nie.

Vir Annette Combrink bied dit een van die vele uitdagings wat vir die Potchefstroomkampus van die Noordwes-Universiteit voor hande lê. Die gevaar het altyd bestaan dat die $\mathrm{CHO}$ as 'n voldoende kenteken van Christelike wetenskap diens kon doen, sonder dat die daad noodwendig by die woord gevoeg hoef te word. Potchefstroom sal in die toekoms nie agter die skans van sy naam kan skuil om die skyn van Christelike wetenskapsbeoefening ten toon te stel nie, maar sal beoordeel word op grond van daadwerklike Skrifmatige denke en arbeid. As oud-PUK is ek vol vertroue dat dit onder professor Combrink se leiding sal geskied! 


\section{Geraadpleegde bronne}

ALSTON, P. 1982. A third generation of solidarity rights: progressive development or obfuscation of international human rights law? Netherlands International Law Review, 29:307-22.

DE GAAY-FORTMAN, B. 2001. Laborious law, inaugural address on accepting the chair in political economy of human rights at Utrecht University, 21 May 2001. http://www.du.edu/humanrights/workingpapers/papers/15degaay fortman-09-01.pdf

DONNELLY, J. 1985. In search of the unicorn: the jurisprudence and politics of the right to development. California Western International Law Journal, 15: 473-507.

JACKSON, T.P. 2003a. A house divided, again: sanctity vs. dignity in the induced death debates. (In Kraynak, R.P. \& Tinder, G.E., eds. In defense of human dignity: essays for our times. Notre Dame: Notre Dame University Press. p. 139-63.)

JACKSON, T.P. 2003b. The priority of love: Christian charity and social justice. Princeton: Princeton University Press.

LEO XIII. 1934 [1891]. Rerum Novarum: Encyclical of Pope Leo XIII on the rights and duties of capital and labour. Herdruk. (In George, H. The conditions of labour. p. 163-95.)

LILLICH, R.B. 1991. International human rights: problems of law, policy and practice. Boston: Little, Brown.

LOCKE, J. 1924 [1689]. Two treatises of civil government. London: Dent.

MARITAIN, J. 1942 [1945]. Les droits de l'homme et la loi naturelle. Paris.

MARKS, S.P. 1981. Emerging human rights: a new generation for the 1980's. Rutgers Law Review, 33:435-452.

PERRY, M.J. 2005. The morality of human rights: a nonreligious ground. Emory Law Journal, 54:97-150.

ROUSSEAU, J.J. 1977 [1762]. Du contrat social; ou principes du droit politique. Paris: Seuil.

SHESTACK, J.J. 1984. The jurisprudence of human rights. (In Meron, T, ed. Human rights in international law: legal and political issues. Oxford: Clarendon. p. 69-113.)

SOHN, L.B. 1982-1983. The new international law: protection of the rights of individuals rather than states. American University Law Review, 32:1-64.

STOKER, H.G. 1970. Die aard en rol van die reg: 'n wysgerige besinning. Johannesburg: RAU. (Publikasie A. 36.)

SUID-AFRIKA. 1996. Grondwet van die Republiek van Suid-Afrika. Wet 108 van 1996.

VAN DER VYVER, J.D. 1994. Stoker se denke aangaande die reg en geregtigheid. Koers, 59:403-434.

VAN DER VYVER, J.D. 2005a. Morality, human rights and foundations of the law. Emory Law Journal, 54:187-200.

VAN DER VYVER, J.D. 2005b. Leuven lectures on religious institutions, religious communities and rights. Leuven: Peeters.

VASAK, K. 1974. Le droit international des droits de l'homme. Académie de Droit International. Recueil des cours, (IV):333-415.

VASAK, K. 1975. Le droit international des droits de l'homme. Institut International des Droits de l'Homme, résumés des cours (sixiéme session d'enseignement). 
VASAK, K. 1977. A 30 year struggle: the sustained efforts to give force of law to the Universal Declaration of Human Rights. UNESCO Courrier, Nov. 1977. p. 29.

VENTER, F. 1986. The Western concept of rights and liberties in the South African Constitution. Comparative \& International Law Journal of South Africa, 19(1):99-111.

\section{Sake}

American Civil Liberties Union v Reno, 217 F 3 d 162

Aschcroft v Free Speech Coalition, 2002535 US 231

Dawood, Shalabi \& Thomas v Minister of Home Affairs, 2000 (3) SA 936

Dawood, Shalabi \& Thomas v Minister of Home Affairs, 2000 (8) BCLR 837 (CC)

Gardiner v Whitaker, 1994 (5) BCLR 10 (EC)

Government of the RSA \& Others v Grootboom \& Others, 2000 (11) BCLR 1168 (CC)

Government of the RSA \& Others v Grootboon \& Others, 2001 (1) SA 46 (CC)

Khosa \& Others $v$ Minister of Social development \& Others; Mahlaule \& Others v Minister of Social Development \& Others, 2004 (6) SA 505 (CC)

Laerskool Middelburg v Departementshoof, Mpumalanga, 2003 (4) SA 160178 $(\mathrm{T})$

RAV v City of St. Paul, 1992505 US 377

Reno v American Civil Liberties Union, 1997521 US 844

$\mathrm{S} \vee$ Makwanyane \& Another, 1995 (3) SA 391 (CC)

$\mathrm{S} \vee$ Williams, 1995 (2) SA 632 (CC)

$S$ v Williams, 1995 (7) BCLR 861 (CC)

Saxbe v Washington Post Co., 1974417 US 843

State v Mitchell, 1993508 US 476

United States v Playboy Entertainment Group Inc., 2000529 US 803

Van Zyl v Jonathan Ball Publishers (Pty) Ltd, 1999 (4) SA 571 (W)

Virginia v Black, 2003538 US 343

\section{Kernbegrippe:}

burgerlike en politieke regte

ekonomiese, sosiale en kultutrele regte

geheiligdheid

menseregte

menswaardigheid

natuurlike regte

ontiese reg

religie

solidariteitsregte 
Key concepts:

civil and political rights

dignity

economic, social and cultural rights

human rights

natural rights

ontic right

religiosity

sanctity

solidarity rights 
